DOI: $10.21554 / \mathrm{hrr} .041807$

\title{
THE RIGHTS OF NATIONAL MINORITIES TO INFORMATION
}

\section{Aid Mršić ${ }^{1}$ \\ Larisa Softić-Gasal}

\author{
Editor on Television of Sarajevo \\ European University „Kallos“ Tuzla, Bosnia and Herzegovina
}

\author{
Original scientific paper
}

\begin{abstract}
The public service, which should be the guardian of the identity of national minorities, fell under the political pressure. In this way, it came out of the scope of its actions. Leading people in independent media believe that the role of the public service is crucial in protecting national minorities.But the media can not do it alone. First of all, the state must regulate, and respect what it has brought. With strong strategies and the inclusion of national minorities in all social trends, it is possible to achieve, not fully, but partially, the equality of all those who liveon the territory of BiH.On the other hand, the public service must respect what the state says. The Communications Regulatory Agency is obliged to impose rules in an adequate manner and at the same time to monitor how much the media (public service) meets its obligations.
\end{abstract}

Keywords: media, national minorities, public service, degradation, equality, freedom

\section{INTRODUCTION}

In transition countries that want democracy, minorities are an indispensable topic. Although communism left us fictitiously long time ago, and democracy came to the big door, it was believed that the problem of minorities would be resolved more quickly. However, it turned out that the inclusion of minorities in the transition process would be more difficult than anybody expected. „The dissolution of Yugoslavia, along with the already existing large number of minority communities, created new ones." (Biserko, 2002, p. 4) Historically, the Balkans is marked by many specifics. „One of them is the late national revolutions. As such as a consequence they had a struggle for ideas that in the meantime were abandoned in Europe, for the creation of an ethnically pure state. Such an idea in Europe has been overcome. It disappeared from the scene because it turned out to be in a certain sense hard to achieve."(Korać, 2002, p. 2) In the context of democratic development, an important segment in the lives of members of national minorities should be the media. In fact, the media should take care of national minorities.However, the connection between them should be strong. The state should provide members of national minorities with free information and education in their languages.

\footnotetext{
${ }^{\mathbf{1} C o r r e s p o n d e n c e ~ t o: ~}$

Aid Mršić, Editor of Television of Sarajevo

Geteova 12/5 71000 Sarajevo, BiH

Phone: +38761606775

E-mail: aidmrsic22@yahoo.com
} 
„For every society, and for mankind as a whole, the fate of minority groups is not just ordinary files like the others. It is, with the fate of women, one of the indicators of moral advancement, or a decline." (Maalouf, 2009, p. 62) It is important to note that the media is crucial in promoting all aspects of life, especially social virtues. Without the media and communication with society, there would be no clear picture of what surrounds us, and the information would come to us very slowly. The inclusion of national minorities in the media in $\mathrm{BiH}$ is very modest. Thereasons are multiple. First of all, the media is not very interested inthe problems of national minorities. At the same time national minorities do not show a great interest to be present in the media.However, the right to have a medium in their own language is guaranteed by the Constitution of $\mathrm{BiH}$, international conventions, as well as domestic legal acts related to the media within the Public Service of $\mathrm{BiH}$.,,The state is obliged to provide a sufficient legal framework for exercising the right to information in minority languages and conditions for funding, so that this right can be realistically realized. However, the primary responsibility for the development of information in minority languages lies with the Association of National Minorities.“(Žigmanov, 2008, p. 116)

\section{Media relations towards national minorities in a dem- ocratic society - minorities are presented as fanatical}

Are democracy and public opinion in $\mathrm{BiH}$ just some of the questions we will try to give answers to? However, we should not expect much, because a society as our own, inert and passive, has not developed this phenomenon enough in contrast to modern societies in which democracy is the key fortheir success. ,The crisis of the modern state is obvious: it protects itself and neglects human rights; a modern state becomes what Duverger called,,a democracy without a people.“" (Vreg, 1991, p. 288) We can not speak of a democratic society if the problem of minorities is not resolved in it, and if a part of the population does not enjoy the same rights that most citizens have. One does not go without another.

Although information in the mother tongue is the fundamental right of every individual, in this case we can exclude this right. The possibility for minority members to be informed in their own language promotes their integration into society and strengthens its cohesion system. „By losing identity, a man is really wondering who he is, and he is increasingly feeling the need to find himself again. As the media spread more and more, the man's need to feel at home well as a citizen of his own town, as strong as a true member of his tribe."(Balle according to Nuhanović, 2010, p. 144) The acceptance of the other is greatly facilitated if the media is open to events in other national communities. But all this fails when we talk about the domestic media sphere.

According to the Communications Regulatory Agency, 41 television stations and 139 radio stations are registered in $\mathrm{BiH}$. None of these media is not primarily targeted at reporting about national minorities. In $\mathrm{BiH}, 12$ daily newspapers and 99 periodicals are published (53 magazines are registered in the Federation and 46 in Republik of Srpska).

We have already said that there are no larger, electronic media that are continuously talking about the rights of national minorities. Printed are sporadic, such as, print edition "Voice of Minorities of the Region" (Glas manjina regije), issued by the Association of National Minorities of Doboj - the financiers are foreigners. There are several other print editions such as the "Jewish Voice" (Jevrejski glas), and the Black and White World magazine or Kbalo-pbarno umal (Crno bijeli svijet) what comes out in the local and Roma language in 2,500 copies. There is also a web portal manjine.ba. However, this portal does not only talk about minorities, but also about other vulnerable categories of the population. Also, the Facebook page of the "National Minority in BiH" (Nacionalne manjine u BiH) can be found, but the administrator is rarely active.

If minorities want to be informed, there must not be a strictly minority medium. They can also be informed through other means of communication, primarily the Public Service, which will speak about their rights through different shows. However, ,the best situation is when there are media on the languages of national minorities, and the worst or most disadvantaged is when there is a minority, but not a minority media, or the possibility for members of the minority to be informed in their mother tongue." (Biserko, 2008, p. 114) This second, unfavorable option is expressed in $\mathrm{BiH}$.

The emphasis is on sensationalism, drama, conflict, deviant behavior to an inappropriate civil society. Entering the art of massacre (Art masacr live) into our homes has become a practice, but this is what spectators, readers, listeners expect.Only minority groups that can be identified with such activities enter the daily news corps. In that way, the information threshold is significant for the decision to publish.

Declaring that the right of national minorities to be informed is not sufficient, it is necessary to show it. In this regard, there is no readiness for the majority of the population to transfer media space to national minorities. „Minorities are generally stereotypically portrayed as „fanatic and fundamentalist.“ (Engineer, 1999, p. 21,32) 
Writing about them is compassionate. The facts are taken selectively (they are often related to petty crime, eg Roma). In that way, the media encourages the spread of stereotypes and prejudices. „Armed with prejudice and stereotypical reporting, the media offers their audience an interpretive framework and models of behavior that are not benevolent to minority communities" (Hodžić and Jusić, according to Van Dijk, 1995, p. 29).

Based on the above, we come to the conclusion that the media promotes the discriminatory use of politically incorrect language and ignores minority issues. „All this tell us that national minorities are in the media ghetto, surrounded by barbed wire, in which they live by imposed rules, or by their own, and the possibilities for any informative upgrade are stunned" (Gajicki, 2008, p. 43). The topics that the media deal with are mostly, according to Van Dajk's studies, the problems that minorities create in society. We will remember the burning of the mistress Ljubica Djokić-Spasojević, who was robbed and burned by people of the Roman origin on the street several years ago. It was a striking news in all the media. This tells us that minorities must be ,the case“, and the causes of the problem, in order to write about them. Apart from being a problem, it is also evident that they are subject to manipulation that is not so portrayed in the media as well as in the society (the Sejdic-Finci case), and it will become when the political powers are most needed to score points. „The media simply gives what is sold well, which maximizes profits." (Thurow to Nuhanović, 2010, p. 142) Many topics which are an integral part of writing when the majority population is concerned, such as economy, politics, society, are missing when we talk about the minority population, although in these areas there are equally good examples and results.National minorities are not residents of the public sphere. They are blocked and isolated, suppressed by those who have privileges, because the group which has the greatest influence in society has its own control and media. Media control by political powers is largely the reason why the media is losing its sense, while at the same time serving only a certain circle of people. Satisfying their wishes and putting them (political elites) at their disposal, the media losesits basic function. Instead of missinforming the public, they should inform it.

\section{RESEARCH}

The research was conducted throughout BiH. Members of 17 national minoritiesparticipated. Albanians ${ }^{2}$, Montenegrins ${ }^{3}$, Czechs ${ }^{4}$, Italians ${ }^{5}$, Jews ${ }^{6}$, Hungarians ${ }^{7}$, Macedonians $^{8}$, Germans ${ }^{9}$, Poles ${ }^{10}$, Roma ${ }^{11}$, Romanians ${ }^{12}$, Russians $^{13}$, Rusins ${ }^{14}$, Slovaks ${ }^{15}$, Slovenians ${ }^{16}$, Turks ${ }^{17}$ i

\section{Ukrainians $^{18}$.}

${ }^{2}$ According to the population census in 1991, there were 4,922 inhabitants in this area, the reference sample for our research was a figure of 492 respondents.

${ }^{3}$ According to the 1991 census, Montenegrins were the largest national minority in Bosnia. Of the 10,048 registered, our reference sample was 1004 .

${ }^{4}$ The Czechs belong to a larger national minority in Bosnia. According to the census on which this research was done, there were 590.

The reference sample for our research was 59 .

${ }^{5}$ Italians also belong to a larger national minority in Bosnia. In the past, 732 lived in the territory of Bosnia. The sample was 73 .

${ }^{6}$ According to the data from 1991, the number of Jews was 426. Our reference sample of $10 \%$ is 42 ..

${ }^{7}$ There were 893 Hungarians 21 years ago. The sample is 89 .

${ }^{8}$ By number, the Macedonian national minority was the sixth in line with the 1991 census. That figure was then 1596. Our reference sample is 159 .

${ }^{9}$ According to the population census what we took as relevant for our research in $\mathrm{BiH}, 470$ German nationals lived. The reference sample was 47.

${ }^{10}$ The Polish national minority in the territory of BiH counted 526 members. A sample of $10 \%$ is 52 .

${ }^{11}$ According to the 1991 census, the Roma were the second largest national minority in $\mathrm{BiH}$. Then there were 8,864. Our reference sample for this research was 886 .

${ }^{12}$ Romanians in Bosnia belong to one of the smallest national minorities. According to the data for which this research was conducted, in 1991, there lived 162 here. Therefore, our valid sample is 16. What is worrying is that there is no Association of the Romanian National Minority, they are not organized in any form. Even the Embassy of Romania in our country has no data on how many of them live in this region. In the survey, individual cases, found with the help of friends and members of other national minorities, took part.

${ }^{13}$ The Russian national minority has a similar destiny as Romania, at least in terms of organization. They do not have an association, and there is no information about their current number in the Embassy in Sarajevo or any other organization. Everything is based on the data from 1991. By that time, 297 of them lived in Bosnia. Our sample was 29. In the survey, individual cases were found through other associations of national minorities and friends.

${ }^{14}$ The smallest national minority in Bosnia is Rusins/Ruthenians. Apart from being the smallest, at the same time they have occupied the most attention. Associations like the previous two national minorities do not have. Information about them, at least of the newer ones, can't be reached. According to the census of 1991, there were 133. Our reference sample is 13 . In this survey, individual cases were involved.

${ }^{15}$ Slovaks in $\mathrm{BiH}$ also belong to a small national minority. According to the census there were 297, and our reference sample was 29. ${ }^{16}$ The number of Slovenians according to the 1991 census was 2,190 . They are among the more numerous national minorities in Bosnia. Their number still moves in these proportions today. Our sample was 219.

${ }^{17}$ Turks in $\mathrm{BiH}$ also belong to a larger national minority. With the data we use in this paper, their number was 267 , and our sample was 26.

${ }^{18}$ Ukrainians, by number, occupy the fourth place in $\mathrm{BiH}$. This national minority according to the 1991 census counted 3,929 members. Our sample was 392. 


\section{Methods andtechniquesof research}

The following research methods will be used in this paper:

- Interview

- Poll

What the media scene offers to national minorities in $\mathrm{BiH}$, certainly is not enough. Below we bring the results of the research.

\section{Mode, organization and process of research}

The Association's chairmen and their members responded to the questions raised in the research. Those members of national minorities who are not organized in the Association participated individu- ally. The study was conducted on a sample of $10 \%$, or 3627 individuals. That is a reference sample according to the 1991 census. It should be noted that the demographic picture of $\mathrm{BiH}$ has changed greatly, and that the current ratio of forces is not the same as that of 1991. For the purpose of this research, the embassies of the countries whose national minorities live in $\mathrm{BiH}$ have been contacted. Most of them did not have the information about the number of their citizens in this area. First of all, this applies to the members of the Russian, Romanian, and also of the Rusins/Ruthenians national minorities. The research was done online and face to face. All the espondents ranswered to six questions, without having to provide their personal information. The research was conducted in six months.

\section{RESULTS AND DISCUSSION}

1. Are national minorities degraded by the media?

\begin{tabular}{lccc}
\hline & YES & NO & PARTIALLY \\
\hline Albanians & $68 \%$ & $11 \%$ & $21 \%$ \\
Montenegrins & $87 \%$ & $4 \%$ & $9 \%$ \\
Czechs & $73 \%$ & $3 \%$ & $24 \%$ \\
Italians & $51 \%$ & $34 \%$ & $15 \%$ \\
Jews & $59 \%$ & $12 \%$ & $29 \%$ \\
Hungarian & $56 \%$ & $32 \%$ & $12 \%$ \\
Macedonian & $59 \%$ & $23 \%$ & $18 \%$ \\
Germans & $66 \%$ & $4 \%$ & $30 \%$ \\
Poles & $75 \%$ & $8 \%$ & $17 \%$ \\
Romans & $72 \%$ & $9 \%$ & $19 \%$ \\
Romanian & $81 \%$ & $19 \%$ & $0 \%$ \\
Russians & $62 \%$ & $0 \%$ & $38 \%$ \\
Rusins/Ruthenians & $92 \%$ & $8 \%$ & $0 \%$ \\
Slovaks & $66 \%$ & $10 \%$ & $24 \%$ \\
Slovenian & $58 \%$ & $34 \%$ & $8 \%$ \\
Turks & $81 \%$ & $0 \%$ & $19 \%$ \\
Ukrainians & $48 \%$ & $19 \%$ & $33 \%$ \\
\hline
\end{tabular}

In the first question, respondents of 17 national minorities could choose one of the three offered answers - Yes, No and Partly. The results we received gave us a confirmation of what we have already mentioned several times.Observing the obtained data, we can see that the greatest dissatisfaction was expressed by the Rusins/Ruthenians. Even $92 \%$ of them believe that minorities are degraded by the media. This question can be viewed individually for a particular minority, but we can also understand it in general terms. After Rusins, there are Montenegrins, Romanians, Turks.
If we carefully analyze the obtained data we can see that a percentage below $50 \%$ is recorded only with Ukrainians, while the others are abovethat number. This data tells us that members of national minorities are dissatisfied with the media relations. On the basis of the obtained results, we can conclude that minorities are not interesting for the media. Out of the total number of 3627 respondents, 2568 of them answered yes to this question, which is more than $70 \% .448$ or $12 \%$ of the respondents choose No for their answer and 611 or $17 \%$ went for Prtially. 
2. Have you ever started an initiative to make a broadcast of the national minority you belong to?

\begin{tabular}{lcc}
\hline & YES & NO \\
\hline Albanians & $24 \%$ & $76 \%$ \\
Montenegrins & $14 \%$ & $86 \%$ \\
Czechs & $27 \%$ & $73 \%$ \\
Italians & $29 \%$ & $71 \%$ \\
Jews & $24 \%$ & $76 \%$ \\
Hungarian & $16 \%$ & $84 \%$ \\
Macedonian & $15 \%$ & $85 \%$ \\
Germans & $45 \%$ & $55 \%$ \\
Poles & $37 \%$ & $63 \%$ \\
Romans & $5 \%$ & $95 \%$ \\
Romanian & $69 \%$ & $31 \%$ \\
Russians & $62 \%$ & $38 \%$ \\
Rusins/Ruthenians & $31 \%$ & $69 \%$ \\
Slovaks & $45 \%$ & $55 \%$ \\
Slovenian & $8 \%$ & $92 \%$ \\
Turks & $19 \%$ & $81 \%$ \\
Ukrainians & $23 \%$ & $77 \%$ \\
\hline
\end{tabular}

Minorities are lethargic, uninterested with a greater presence in the media. But these results should not be confusing. Minorities are passive, but this is not the reason for their media absence. Most of the members of national minorities, that show the results of our survey, have never started an initiative to create a television or radio show about them. Nearly all, except for two, this percentage is above $55 \%$.

$95 \%$. Although according to some indicators they are the highest in $\mathrm{BiH}$ today, most of them are apathetic. They are followed by Slovenians, Montenegrins, Macedonians. These results give us the right to say that minorities do not care about themselves. They do not strive to improve their position in the media, and have presented themselves to the general public in a different way.Out of the 3627 respondents, 587 Surprisingly, the highest percentage is again among or 16\% answered YES as their answer, while 3040 or members of the Roma national minority and it is $84 \%$ chose NO.

3. Do you think that within the Public Services there should be channels in the languages of national minorities, or at least broadcasts?

\begin{tabular}{lccc}
\hline & YES & NO & MAYBE \\
\hline Albanians & $72 \%$ & $11 \%$ & $17 \%$ \\
Montenegrins & $93 \%$ & $2 \%$ & $5 \%$ \\
Czechs & $81 \%$ & $3 \%$ & $16 \%$ \\
Italians & $80 \%$ & $16 \%$ & $4 \%$ \\
Jews & $83 \%$ & $17 \%$ & $0 \%$ \\
Hungarian & $80 \%$ & $17 \%$ & $3 \%$ \\
Macedonian & $67 \%$ & $23 \%$ & $10 \%$ \\
Germans & $70 \%$ & $28 \%$ & $2 \%$ \\
Poles & $90 \%$ & $0 \%$ & $10 \%$ \\
Romans & $87 \%$ & $2 \%$ & $11 \%$ \\
Romanian & $81 \%$ & $19 \%$ & $0 \%$ \\
Russians & $62 \%$ & $14 \%$ & $24 \%$ \\
Rusins/Ruthenians & $85 \%$ & $15 \%$ & $0 \%$ \\
Slovaks & $79 \%$ & $4 \%$ & $17 \%$ \\
Slovenian & $75 \%$ & $17 \%$ & $8 \%$ \\
Turks & $73 \%$ & $23 \%$ & $4 \%$ \\
Ukrainians & $81 \%$ & $9 \%$ & $10 \%$ \\
\hline
\end{tabular}


The public service should have a channel in the languages of national minorities, or at least emissions. This is the opinion of most respondents. The percentage of the answer does not go below $60 \%$.In the case of members of the Montenegrin national minority, it reaches $93 \%$, and in the Poles $90 \%$. The fewest answers with Yes, were Macedonians $67 \%$ and Russians $62 \%$.A few respondents consider that they should not have a show or channel in their own language. This is among Germans expressed in $28 \%$ of cases, and this is the highest percentage.

To what extent are national minorities interested in the channel, or at least the broadcast in the language of the minority also shows collective results. 3031 or $84 \%$ of respondents answered that the Public Service should have such a thing. An incomparably smaller number of 263 or $7 \%$ think that it does not need, while 333 or $9 \%$ of respondents consider that it may need a channel or broadcast.

4. What is the position of the minority you belong to in relation to the majority?

\begin{tabular}{lccc}
\hline & GOOD & BAD & I DON'T KNOW \\
\hline Albanians & $18 \%$ & $53 \%$ & $29 \%$ \\
Montenegrins & $6 \%$ & $69 \%$ & $25 \%$ \\
Czechs & $19 \%$ & $61 \%$ & $20 \%$ \\
Italians & $19 \%$ & $51 \%$ & $30 \%$ \\
Jews & $33 \%$ & $48 \%$ & $19 \%$ \\
Hungarian & $35 \%$ & $55 \%$ & $10 \%$ \\
Macedonian & $16 \%$ & $45 \%$ & $39 \%$ \\
Germans & $55 \%$ & $45 \%$ & $0 \%$ \\
Poles & $35 \%$ & $53 \%$ & $13 \%$ \\
Romans & $24 \%$ & $70 \%$ & $6 \%$ \\
Romanian & $6 \%$ & $81 \%$ & $13 \%$ \\
Russians & $7 \%$ & $65 \%$ & $28 \%$ \\
Rusins/Ruthenians & $31 \%$ & $54 \%$ & $15 \%$ \\
Slovaks & $13 \%$ & $61 \%$ & $26 \%$ \\
Slovenian & $9 \%$ & $62 \%$ & $29 \%$ \\
Turks & $31 \%$ & $50 \%$ & $19 \%$ \\
Ukrainians & $22 \%$ & $41 \%$ & $37 \%$ \\
\hline
\end{tabular}

It is very important what minorities think about their position in the society. Are they neglected, left to themselves, or viewed with special care?

Most respondents within 17 national minorities think that their position is bad. Each of these is expressed in more than 40 percent. Romanians are the foremost in this. In $81 \%$ of the cases, they find that their position is poor. They are followed by
Roma with $70 \%$, and Montenegrins with $69 \%$. In total, 627 respondents or $\mathbf{1 7 \%}$ answered Good, 2212 or $61 \%$ Poor, and 788 or $22 \%$ do not know. From this analysis we can see that minorities are not satisfied with their position in relation to the majority. We would say for a good reason, because the position the majority have in the society is not guaranteed for the minorities 
5. Do you, as a member of a national minority, feel free in the Bosnian society?

\begin{tabular}{lcc}
\hline & YES & NO \\
\hline Albanians & $89 \%$ & $11 \%$ \\
Montenegrins & $96 \%$ & $4 \%$ \\
Czechs & $100 \%$ & $0 \%$ \\
Italians & $100 \%$ & $0 \%$ \\
Jews & $98 \%$ & $2 \%$ \\
Hungarian & $100 \%$ & $0 \%$ \\
Macedonian & $100 \%$ & $0 \%$ \\
Germans & $100 \%$ & $0 \%$ \\
Poles & $100 \%$ & $0 \%$ \\
Romans & $93 \%$ & $7 \%$ \\
Romanian & $100 \%$ & $0 \%$ \\
Russians & $86 \%$ & $14 \%$ \\
Rusins/Ruthenians & $100 \%$ & $0 \%$ \\
Slovaks & $93 \%$ & $7 \%$ \\
Slovenian & $93 \%$ & $7 \%$ \\
Turks & $100 \%$ & $0 \%$ \\
Ukrainians & $81 \%$ & $19 \%$ \\
\hline
\end{tabular}

Being free is important for every individual or group. free, then we can consider that the majority are satSo it should be with us. Freedom is the fundamen- isfied. The remaining eight national minorities have tal right of every human being. $89 \%$ of Albanians, members who do not feel free, but this percentage is and $96 \%$ of Montenegrins responded to feel free. In small and it ranges from 19\% among Ukrainians to Czech, the feeling of freedom is $100 \%$, as well as respondents of the Jewish national minority, which with Italians, Hungarians, Macedonians, Germans, is two percent.Even the total number of respondents Poles, Romanians, Rusins and Turks. In others, this goes in a positive direction, so we have 3369 or $93 \%$ is expressed in a slightly lower percentage.If nine na- of the respondents to feel free, and 258 or $7 \%$ who do tional minorities, or their members think that they feel not feel free.

6. Do you, as a member of national minority, feel equal to others in the Bosnian society?

\begin{tabular}{|c|c|c|}
\hline & YES & NO \\
\hline Albanians & $3 \%$ & $97 \%$ \\
\hline Montenegrins & $25 \%$ & $75 \%$ \\
\hline Czechs & $27 \%$ & $73 \%$ \\
\hline Italians & $36 \%$ & $64 \%$ \\
\hline Jews & $29 \%$ & $71 \%$ \\
\hline Hungarian & $42 \%$ & $58 \%$ \\
\hline Macedonian & $14 \%$ & $86 \%$ \\
\hline Germans & $13 \%$ & $87 \%$ \\
\hline Poles & $44 \%$ & $56 \%$ \\
\hline Romans & $3 \%$ & $97 \%$ \\
\hline Romanian & $69 \%$ & $31 \%$ \\
\hline Russians & $3 \%$ & $97 \%$ \\
\hline Rusins/Ruthenians & $38 \%$ & $62 \%$ \\
\hline Slovaks & $48 \%$ & $52 \%$ \\
\hline Slovenian & $41 \%$ & $59 \%$ \\
\hline Turks & $46 \%$ & $54 \%$ \\
\hline Ukrainians & $28 \%$ & $72 \%$ \\
\hline
\end{tabular}


Freedom and equality are two different concepts. Discrimination is present in every form. Members of national minorities have no equal rights as constituent peoples in this country. They do not have their media, educational and cultural institutions ... They do not feel equal in any segment of social activity. On the basis of the obtained results, Albanians, Roma and Russians feel at least equal to others. The survey shows that only members of one national minority exceed $50 \%$ of positive answers.In total, 678 respondents or 19\% answered that they felt equall, while 2949 or $81 \%$ answered No (not feeling equall with others).

\section{Fake creation of media multiculturalism - Public ser- vices became commercial media}

The Bosnian-Herzegovinian media scene, over the past decade of a socio-political shift from autocracy to democracy, has been facingwith the problem of establishing a satisfactory value system for creating a media policy that will respect the specific political, cultural and economic objectives of this area, but also to meet European democratic standards. "So far, media policy has not yet been fully defined, despite the principle of ,pluralism and diversity of the media in the political and social system that should also contribute to us with goals such as „freedom and openness of the media with different ideas, and the critical role of the media in political and social system“ (Zgrabljić, 2003, p. 60; Antunović, 2000, p. 45).

In public service programs you can see everything except what is related to our topic. It is expected to be at the service of everyone. When we say this, then first of all we are thinking of the citizens. It's their service, their voice is against, or for someone and something. However, the public service in $\mathrm{BiH}$ is far from that. The public, no matter what kind it was,excluded from all segments of the creation of a public service program. Here we alludate to certain groups that, according to their small or no influence, can (not) be represented in the programs of public broadcasters. And it is precisely on this basis that ,the civil public stands and falls under the principle of general availability. The public from which certain groups would be ,eo ipso“ excluded is not only incomplete, but it is not a public either" (Habermars, 1969, p. 110).

We know that members of national minorities are not only excluded from the public sphere, but also by the Law, and by Constitution of this country in an unequal position with,,others“" ethnic, majority population. Although the Law on Public Broadcasting Service of $\mathrm{BiH}$ requires that through the content they must affirm the cultural and other needs of national minorities, there have not even been any objections to possible discriminatory content against them. The data we receive shows that national minorities in $\mathrm{BiH}$ are media degraded. This will also confirm our first question, as well as the answers received. Neglected are not any other issues. It showsthat national minorities want a show or channel in their own language. This, perhaps, is unrealistic to expect, but it needs to be taken seriously for consideration. And as they seek their rights, in order to preserve their identity, they are disputed by the same rights. There were also several issues related to the rights of members of national minorities. Perhaps not directly, but from the question, „do you feel the same in the Bosnian society"much can be concluded. The answers are devastating. However, to conduct a survey and among the constituent peoples in this country we would surely get similar results, because everyone in this country feels threatened. This is a real overview of how society treats national minorities. Finally, the results obtained gave as a true picture of the society, the media and the state where we struggle for survival alone, without any help. In the end, we should not forget one thing.Europe rests on the foundations of diversity, where it is respected, and not rejected. As we have seen, the situation is not harmless. The data obtained can be compared in several ways.

\section{CONCLUSION}

When we talk about rebuffing members of national minorities and their rights, we should not go further than the region. We see how the countries who are preparing to join the EU regulate these segments. They are far ahead of us. To be a serious player throughout this story, one of the tasks is to solve the problems and status of national minorities in the society. However, one should not forget, that the situation in our country is somewhat more complex. It took a long time to present multiculturalism as the only possible and sustainable one. Authority has not always been interested in resolving such issues. However, the desire to pay more attention to minorities has resulted in numerous laws and initiatives. The minorities themselves also took an active part in social and political life. Understanding and work have led to the fact that national minorities are not forgotten.Nevertheless, all laws are dead letters on paper. The struggle for armchairs led us to a situation where there is no place for national minorities. The fact that the media does not pay enough attention speaks to the fact that we did not recognize the problem within our community. But in multicultural Europe there is no room for one or the other, but for everyone equally. 


\section{REFERENCES}

Antunović, Ž. (2000). Ten Years after - A New Strategy for Independent and Pluralistic Media in Croatia, Opening speeche, (Deset godina poslije. Nova strategija za neovisne i pluralističke medije u Hrvatskoj, uvodno izlaganje, Media Reserach, Medijska istraživanja, 6(2)., pp. 45-49

Biserko, S. (2008). Informativni resursi manjina i očuvanje multietničkog identiteta Vojvodine, in Multietnički identitet Vojvodine izazovi u 2007-08, u Helsinške sveske, 27. Beograd: Helsinški odbor za ljudska prava u Srbiji. pp. 113-114

Biserko, S. (2002). Većinski nacionalizam proizvodi manjinski, u Manjine i tranzicija, Helsinške sveske, 12, Beograd: Helsinški odbor za ljudska prava u Srbiji. p. 4

Engineer, A. A. (1999). Media and Minorities: Exclusion, Distorsion and Stereothypes. Economic and Political Weekly

Gajicki, M. (2008). Život u getu. u Multietnički identitet Vojvodine izazovi u 2007-08, Helsinške sveske, 27. Beograd: Helsinški odbor za ljudska prava u Srbiji. pp. 43-45

Habermas, J. (1969). Javno Mnenje - Istraživanje u oblasti jedne kategorije građanskog društva. Beograd: Kultura
Hodžić, E. \& Jusić, T. (2010). Na marginama: Manjine i mediji u jugoistočnoj Evropi. Sarajevo: Mediacentar

Kanižaj, I. (2006). Manjine između javnosti i stvarnosti, Zagreb: JETiC

Korać, Ž. (2002). Nije lako biti manjina na Balkanu u Tranzicija i položaj manjina, Helsinške sveske, 12. Beograd: Helsinški odbor za ljudska prava u Srbiji.. p. 2

Maaluf, A. (2009). Poremećenost sveta. Beograd: Laguna

Nuhanović, A. (2010). Demokratija, mediji, javnost-Ogled o slobodi i jednakosti. Sarajevo: Promocult

Vreg, F. (1991). Demokratsko Komuniciranje. Sarajevo: NUB $\mathrm{BiH}$

Zgrabljić, N. (2003). Hrvatska medijska politika i javni mediji. Medijsko istraživanje, 9 (1), pp. 59-57

Žigmanov, T. (2008a), U poziciji prvih kršćana, u Multietnički identitet Vojvodine izazovi u 2007-08, u Helsinške sveske, 27. Beograd: Helsinški odbor za ljudska prava u Srbiji. p. 48

Žigmanov, T. (2008b). Informisanje na jezicima nacionalnih manjina u Republici Srbiji, u Multietnički identitet Vojvodine izazovi u 2007-08, u Helsinške sveske, 27. Beograd: Helsinški odbor za ljudska prava u Srbiji. p. 116. 